\title{
PAHs as quality markers of the sediments in the Lower Taquari sub- basin during the period of intervention in a contaminated site
}

\author{
Gameiro, P.H. ${ }^{1}$; Pereira, N.C. ${ }^{2}$; Rocha, J.A.V. ${ }^{2}$, Leal, K.A. ${ }^{2}, \&$ Vargas, V.M.F. ${ }^{1}$ \\ ${ }^{1}$ Programa de Pós-graduação em Ecologia, Universidade Federal do Rio Grande do Sul (UFRGS), Av. Bento Gonçalves, \\ 9500, 91501-970, Porto Alegre, RS, Brazil. \\ ${ }^{2}$ Departamento de Pesquisas e Análises Laboratoriais, Fundação Estadual de Proteção Ambiental Henrique Luís Roessler (FEPAM), \\ Rua Aurélio Porto, 37, 90620-090 Porto Alegre, RS, Brazil
}

Received November 13, 2017; Accept April 9, 2018

\begin{abstract}
The region studied on the Taquari River, is close to a site with soil contaminated by wood preservatives, where a route of contaminants into the river was identified. This site was submitted to the first stage of the intervention process excavating the soil to remove the main active sources. To assess sediment quality the PAHs concentrations were analyzed: before, during and after the process. The PAHs concentration was compared to the guide values adopted by CONAMA resolution 344/04, aiming to protect aquatic life. Four points on Taquari River were tested, upper (TA032), in front (TA010) and lower (TA006, TA004) the contaminated site. Besides these, the Stream that is considered a source of contamination for TA010 was evaluated in the last step. The results indicated values between ISQG (Interim Sediment Quality Guidelines and PEL (Probable Effect Level) observed for eight PAHs. The PAHs values, probably carcinogenic to humans, were between ISQG and PEL in different samplings at TA010, more expressives during and after intervention. These values were also found at TA006 and TA004 during the same periods. The persistent contamination of the critical point TA010, even after intervention, is a warning regarding the environmental quality and aquatic life of this region.
\end{abstract}

Key words: Wood preservatives; runoff of compounds, PAHs, intervention process

\section{INTRODUCTION}

The pollution of aquatic environments is a worldwide problem, and its most evident consequences are: the scarcity of clean sources of supply and the death of organisms. The sources of contamination are attributed to the industrial, agricultural, commercial and domestic wastes (Claxton et al., 1998), or even contaminated soils (Chen \& White, 2004; Costa et al., 2012; 2017).

Several studies on the effects of contaminants on aquatic organisms resulted establishing sediment quality criteria aiming to protect aquatic life. The Companhia Ambiental do Estado de São Paulo (CETESB) used these criteria based on guide values established by the Canadian Council of Ministers of the Environment (CETESB, 2006; CCME, 1999) for arsenic, heavy metals and organic compounds. The same guide values were adopted by Conselho Nacional do Meio Ambiente (CONAMA) Resolution 344/04 (Brasil, 2004), which establishes guidelines and minimum procedures to evaluate the dredged material. This guide provides information about the values of ISQG (Interim Sediment Quality Guidelines) which represents the guiding value of reference for sediment quality, also TEL (Threshold Effect Level), the concentration below which adverse effects are rarely expected for the organisms and the value of PEL (Probable Effect Level), which represents the concentration above which a deleterious effect on the biota is often expected. In the range between TEL and PEL lie the values where these effects are occasionally expected (CCME, 1999; CETESB, 2006).

This study focuses on the consequences of contamination in an area that, from the 1960 s to 2005 , had a wood 
preservation plant with an already identified environmental problem. During the time in which it was active the industry used as wood preservatives: pentachlorophenol (PCP), a dioxin precursor; creosote, formed by Polycyclic Aromatic Hydrocarbons (PAHs); and chromated copper arseniate (CCA), with high toxic and/or genotoxic and/ or carcinogenic potentials (Appel et al., 2007). Among the studies already performed in this area, it was possible to indicate the presence of these compounds and PAHs were detected) detected, both in samples of soil inside the company, in domestic dust and atmospheric compartment (Coronas et al., 2013; Pohren et al., 2012). It was also possible to define these compounds as chemical markers of contaminant routes from the soil into the main river, in association with the Salmonella/microsome assay (Costa et al., 2012; 2017). Sediment sampling sites at Taquari River were affected by PAHs and presented a mutagenic response that was identified as a possible consequence of this drainage (Costa et al., 2012; 2017). Currently the company is no longer active and was included in the studies of environmental impact of the Fundação Estadual de Proteção Ambiental Henrique Luís Roessler (FEPAM), which authorized the first phase of the soil intervention process. This has already been performed by removing the main active sources.

The present study prioritized PAHs as markers of sediment quality aiming to protect aquatic life in a Taquari River area subject to sites contaminated with wood preservatives in different periods of an intervention process.

\section{MATERIALS AND METHODS}

\section{Study area}

The study was performed in Taquari River, which belongs to the Taquari-Antas Basin, in the municipality of Triunfo, south Brazil. This stretch of the river is under the influence of a site contaminated by a wood preservative since 1960 . The intervention to remove the main active sources from this site was performed from 2012 to 2013 . This includes areas for processing, treatment, storage tanks and waste dump; areas with drums buried on company land and in a neighboring tree farm, besides the removal of the building from the plant. The soils and residues were disposed of in a landfill for hazardous residues or an incineration unit, according to concentration and contaminants present. Engineering processes, using containment barriers to avoid pollutant dispersion, protected the excavated areas.

Four sampling points were chosen in the Taquari River (named according to the initial letters of the river, Ta, followed by the number of kilometers from the mouth) (Figure 1). In the last sampling, in addition to the points of the main river, in a stream, to be called Stream with the mouth located upper from the point Ta010. This Stream is considered one of the contaminant runoff routes from the soil to the Taquari River (FEPAM, 2010; Costa et al., 2012; 2017).

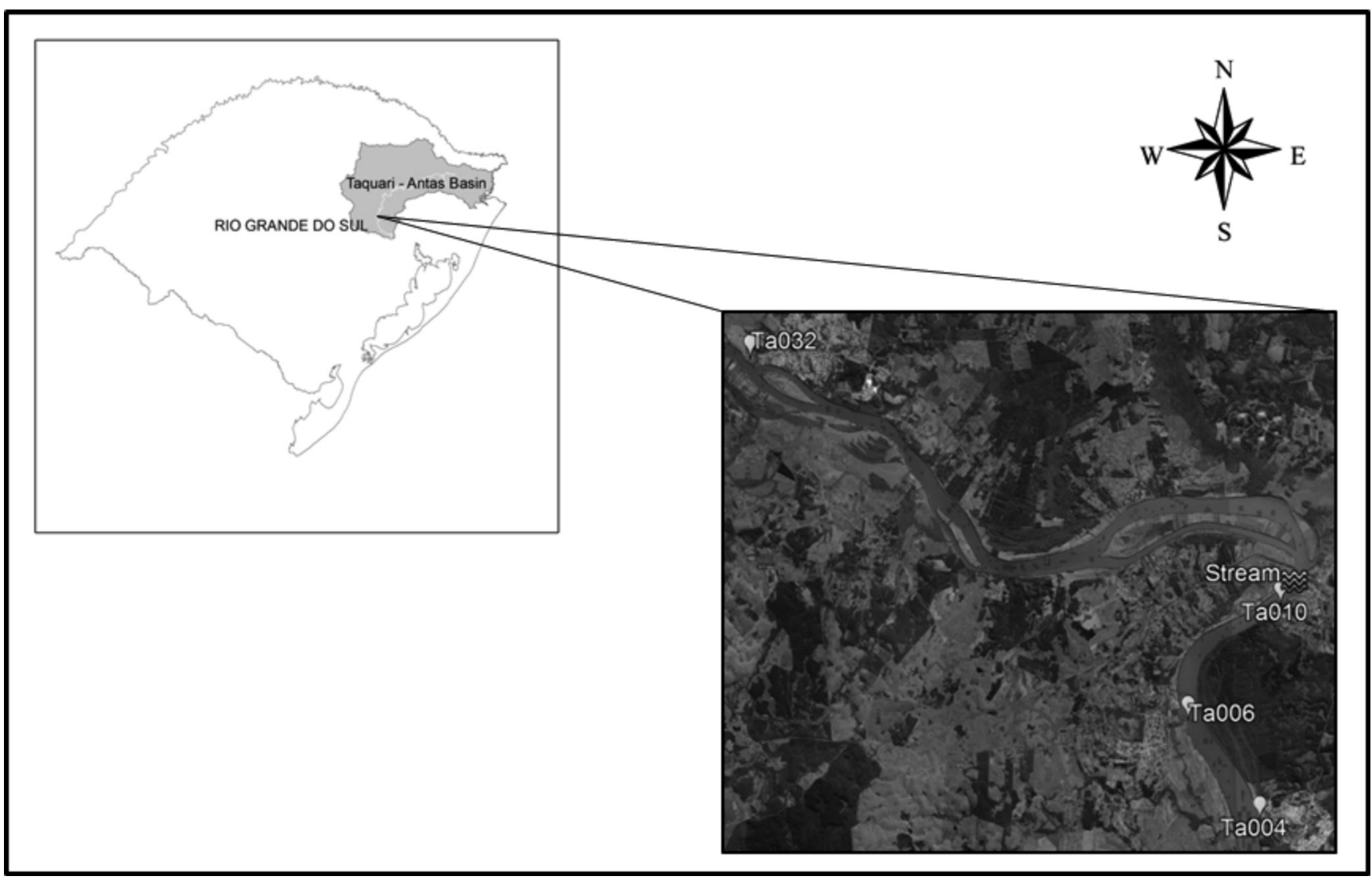

Figure 1. The Taquari-Antas River Basin, sampling areas in the Taquari River, Ta032, Ta010 Ta006, Ta004 and the Stream inside the contaminated site. The numbers show the distance from the mouth in kilometers. 


\section{Sample collection}

The sediment samplings in the Taquari River were performed during the period from 2011 to 2013, before (winter and summer), during (summer) and after (summer) the intervention process at the site of the contaminated soil. The specifications of the sampling points in Taquari River, their location, geographic coordinates and main uses are described in table 1. The sediment compound samples were collected using a Petersen dredge, at approximately $20 \mathrm{~cm}$ from the river bed (APHA, 1992). The samples were homogenized and stored in a freezer $\left(-20^{\circ} \mathrm{C}\right)$ until the analyses were performed. The stream was sampled only on the last date of collection, in order to find out whether after the intervention process contaminant runoff occurred from the soil in the river, as already detected by Costa et al $(2012 ; 2017)$.

\section{Extraction procedure and quantification}

The aliquots of the organic extracts were obtained using the USEPA method (Method 3550C, Ultrasonic extraction, 2007). Therefore, $2 \mathrm{~g}$ of dry sample in sodium sulfate $\left(\mathrm{Na}_{2} \mathrm{SO}_{4}\right)$ were used and the solvent (DCM - CASRN 75-09-2) was added and placed in ultrasound (THORNTON - power $1800 \mathrm{~W}$ ) in a three minute water bath. The samples were filtered and their volumes reduced with nitrogen gas. Next, the extracts were cleaned using a silica gel column (CASNR 112926-008 , VETEC) with hexane/dichloromethane and the volume was reduced to $1 \mathrm{~mL}$.

The extracts were analyzed by gas chromatography connected to a mass spectrophotometer (GCMS Shimadzu QP2010 by SIM - single ion monitoring). The capillary column used was a DB-5 MS (10 m x $0.10 \mathrm{~mm}$ i.d. x 0.10 $\mu \mathrm{m}$ film thickness). The injector and interface temperature was $310^{\circ} \mathrm{C}$. The initial $\mathrm{GC}$ temperature was $50^{\circ} \mathrm{C}$ then ramped $9^{\circ} \mathrm{C} \mathrm{min}{ }^{-1}$. One microliter was injected in splitless mode. The limits of detection (LOD) and limits of quantification (LOQ) for the fifteen PAHs (two compounds were grouped together) were found in the range of 0.001 and $0.118 \mu \mathrm{g}^{-1}$ and 0.010 and $1.175 \mu \mathrm{g} \mathrm{L}^{-1}$, respectively. The coefficient of determination ranged from 0.9949 to 1.000 and the relative standard deviations ranged from 0.0222 to 1.2665 .

\section{RESULTS AND DISCUSSION}

The investigation of contaminant runoff from soil to Taquari River sediment highlighted this pollutant dispersion route, helping to define the sources of compounds that contribute to the complexity of hazardous mixtures detected in that sediment samples tested. In this mixture of organic compounds expected at the critical point Ta010 are the PAHs, probably from the creosote. Eight (in this case seven, since two compounds were grouped together) of the sixteen PAHs analyzed are classified by the International Agency for Research on Cancer (IARC, 2010), as group 1 (carcinogenic to man: benzo(a)pyrene), group 2A (probably carcinogenic to man: dibenzo(ah)anthracene) or group 2B (possibly carcinogenic to man: naphthalene, benzo(a)anthracene, chrysene, benzo(b+k) fluoranthene, indeno (1,2,3-cd-pyrene). In this study these seven PAHs were expressed in the results as carcinogenic. Acenaphthylene, acenaphthene, fluorine, phenanthrene, anthracene, fluoranthene, pyrene and benzo(ghi)perylene were expressed as other PAHs. The sum of the concentrations of these compounds, in the four samplings, is shown in figure 2.

The concentrations of the total PAHs in the river sediment were more evident after the intervention process in the contaminated soil at all sampling points, shown in figure 2 . Among them, Ta010 showed higher PAHs contents in all periods. After the procedure they were the highest $(912 \mu \mathrm{g} /$ $\mathrm{Kg}$ ) including the predominance of those that are considered carcinogenic to man. The results observed for the stream $(1191.8 \mu \mathrm{g} / \mathrm{Kg})$ indicated that it might possibly contribute to the contamination of Ta010. At points $\mathrm{Ta} 006$ and Ta004 lower total PAHs concentrations were found in the previous samplings and during the treatment, but after the procedure, these levels were higher. Thus, the carcinogenic PAHs concentrations were higher than at the other PAHs in most of samplings. These high responses were also present in previous studies at Ta006 (Costa et al, 2012; 2017), showing values

Table I. The specifications of the sampling points in Taquari River, their location, geographic coordinates and main uses

\begin{tabular}{|c|c|c|c|}
\hline Local $^{\mathrm{a}}$ & City & Geographic coordinates & Uses \\
\hline Ta032 & Taquari & $29^{\circ} 48^{\prime} 19.2^{\prime \prime S} 51^{\circ} 52^{\prime} 50.2^{\prime \prime} \mathrm{W}$ & $\begin{array}{l}\text { Tourism and leisure. Fishing, water intakes for public } \\
\text { supply, waterway transport, sand and rock extraction, } \\
\text { irrigated agriculture }\end{array}$ \\
\hline Ta010 & Triunfo & $29^{\circ} 52^{\prime} 23.9^{\prime \prime S} 51^{\circ} 43$ ‘21.99 “W & Wood preservatives plant, waterway transport \\
\hline Ta006 $^{\mathrm{b}}$ & General Câmara & $29^{\circ} 54^{\prime} 09.7^{\prime \prime S} 51^{\circ} 45^{\prime} 05.1^{\prime \prime W}$ & $\begin{array}{l}\text { Water intake for public supply; fishing, waterway } \\
\text { transport; Rice crop irrigation; recreation; sand, gravel } \\
\text { and clay extraction; preserved wood }\end{array}$ \\
\hline Ta004 & Triunfo & $29^{\circ} 55^{\prime} 45.2^{\prime \prime} \mathrm{S} 51^{\circ} 43^{\prime} 50.4^{\prime \prime} \mathrm{W}$ & $\begin{array}{l}\text { Quay, irrigated agriculture, fishing, sand dredging, } \\
\text { waterway transport. }\end{array}$ \\
\hline Stream $^{\mathrm{c}}$ & Triunfo & $29^{\circ} 52^{\prime} 14.19^{\prime \prime} \mathrm{S} 51^{\circ} 43^{\prime} 6.73^{\prime \prime} \mathrm{W}$ & Wood preservatives plant, waterway transport \\
\hline
\end{tabular}

${ }^{a}$ The numbers show the distance from the mouth in kilometers.

bPoint located on the left bank due to the presence of a curve on Taquari river;

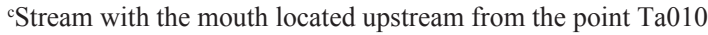




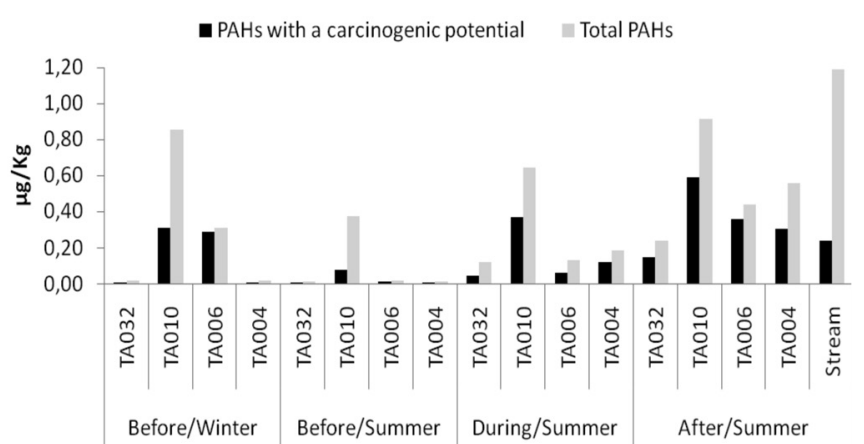

Figure 2. Total PAH concentrations, emphasizing in the sum the PAHs carcinogenic potential (Group 1: carcinogenic to humans, Group 2A: probably carcinogenic to humans, Group $2 \mathrm{~B}$ : possibly carcinogenic to humans) and non carcinogenic PAHs.

higher than the critical point, Ta010. At the upper point Ta032 the lowest concentrations of PAHs were observed.

Canadian legislation (CCME, 1999) establishes guide values for twelve PAHs, of the sixteen considered a priority by the International Agency for Research on Cancer (IARC). The concentrations of PAHs were compared to the sediment quality guideline. The results showed that the values between ISQG (or TEL) and PEL were observed for eight PAHs found in Taquari River, including: naphthalene, acenaphthylene, acenaphthene, fluorine, phenanthrene, fluoranthene, pyrene and dibenzo(ah) anthracene. However, benzo(a) pyrene benzo(a)anthracene, chrysene and anthracene presented values lower than TEL (Table 2).

Among the PAHs that are probably carcinogenic to man, only naphthalene and dibenzo(ah)anthracene present values that could have effects on the organisms, preponderantly in the periods during and after intervention. The point Ta010 presented values between ISQG and PEL in the different samplings, which were also more expressive during and after the intervention. These values were also intensified progressively at points lower from the contaminated site, $\mathrm{Ta} 006$ and $\mathrm{Ta} 004$ during these periods. In the stream also a large number of compounds with values between ISQG and PEL could be noted and for acenaphthylene contents greater than PEL were observed $(100.5 \mu \mathrm{g} / \mathrm{Kg})$, the concentration above which damage to organisms is expected.

Comparing the results to the guide-values ISQG and PEL for PAHs, these data suggest attention by the environmental agencies, since it was possible to identify that sediment quality had decreased in the areas most influenced by the contaminated site. A similar result was observed in surface sediments of Mithi River, India where a moderate impact of PAHs was reported based on the Sediment Quality Guidelines (SQG) value (Singare, 2015).

The chemical composition of the aquatic medium is very complex, allowing multiple interactions between biotic and abiotic components, generating synergistic, antagonistic and toxic effects. Regardless of the origin of PAHs in sediments, aquatic organisms may be adversely affected by exposure

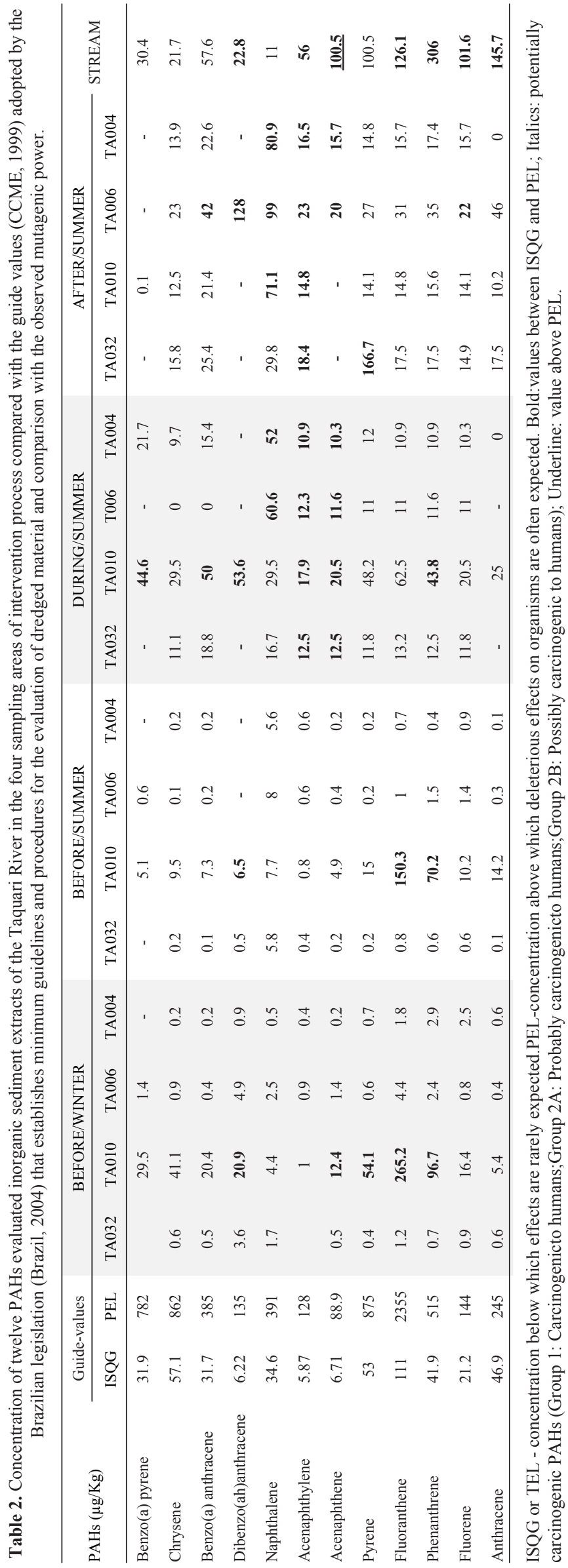


to elevated levels. This response depends on the sensitivity of individual species and the bioavailability of PAHs is influenced by several factors, including physicochemical properties of the PAH, geochemical factors, and biological factors (CCME, 1999). The roles of the various factors that modify the bioavailability of PAHs should be considered, along with the recommended ISQGs and PELs, in site-specific assessments of PAHs in sediments.

Concluding this study, we highlight that in the list of guide values of PAHs in the Canadian legislation, four of the 16 PAHs considered a priority by IARC are not covered: benzo(b)fluoranthene, benzo(k)fluoranthene, indeno(1,2,3cd-pyrene, considered possibly carcinogenic to man and benzo(ghi) perylene, which is toxic but does not present sufficient evidence of carcinogenicity to man. Furthermore, the adoption of ISQGs and PELs allowed evidencing the presence of hazardous contaminants at $\mathrm{Ta} 010$ and at the points in the lower contaminated site (Ta006 and Ta004), even after the intervention. It evidenced the Stream as the source of runoff of hazardous compounds from the contaminated site. The guide-values found at these points were those that could occasionally generate some effect on the biota, or even above which damage to organisms is expected. Therefore, measures for safer interventions to remove contaminants should be taken to prevent the fauna and flora being affected by human activities. The continuity of this process will be decided by FEPAM, according to the operating license to be implemented.

\section{ACKNOWLEDGEMENTS}

The authors thank the Coordenação de Aperfeiçoamento de Pessoal de Nivel Superior for the MSc. scholarship granted to Paula H. Gameiro and the Fundação de Amparo à Pesquisa do Estado do Rio Grande do Sul for the scientific initiation scholarship given to Naiara C. Pereira. We also thank the sampling group of FEPAM and the Bioassays Laboratory for part of the PAHs analyses. The study was supported by the Conselho Nacional de Desenvolvimento Científico e Tecnológico (CNPq 397884/2011-2; 479566/2012-7).

\section{REFERENCES}

APHA. Standart Methods For The Examination Of Water And Wastewater. American Public Health Association, American Water Works Association and Water Environment Federation.18th eds. M.A.H Franson, Washington, p. 1-20, 1992.

APPEL, J.S.L.; TERESCOVA, V.; RODRIGUES, V.C.B.; VARGA, V.M.F. 2007. Aspectos toxicológicos do preservativo de madeira CCA (arseniato de cobre cromato): revisão. Rev Bras Toxicol. 19: $29-43$.

BRASIL, 2004. Conselho Nacional do Meio Ambiente - Resolução
CONAMA $\mathrm{n}^{\mathrm{o}}$ 344, de 25 de março de 2004. Dispõe sobre diretrizes gerais e os procedimentos mínimos para a avaliação do material a ser dragado em águas jurisdicionais brasileiras, e dá outras providências. Disponível em: <http://www.mma.gov. br/conama>. Acessed in: 03 dez. 2014.

CCME - Canadian Sediment Quality Guidelines for the Protection of Aquatic Life- Polycyclic aromatic hydrocarbons. 1999. Canadian Environmental Quality Guidelines - Summary Tables.

CETESB (Companhia Ambiental do Estado de São Paulo). 2006. Critérios para avaliação da qualidade de sedimento - Anexo VI. Série Relatórios. São Paulo: CETESB, 4p.

CHEN, G. \& WHITE, P.A. 2004. The mutagenic hazards of aquatic sediments: a review. Mutat Res. 567: 151-225. https:// doi:10.1016/j.mrrev.2004.08.005

CLAXTON, L.D.; HOUK, V.S.; HUNGHES, T. J. 1998. Genotoxicity of industrial wastes and effluents. Mutat.Res. 410:237-243. https://doi.org/10.1016/S1383-5742(98)00008-8

CORONAS, M.V.; BAVARESCO, J.;, ROCHA, J.A.V.; GELLE, A.M.; CARAMÃO, E.B.; RODRIGUES, M.L.K.; VARGAS, V.M.F. 2013. Attic dust assessment near a wood treatment plant: Past air pollution and potential exposure. Ecotoxicol Environ Saf.. 95:153-160. http://dx.doi.org/10.1016/j.ecoenv.2013.05.033

COSTA, T.C.; BRITO, K.C.T.; ROCHA, J.A.V.; LEAL, K. A. RODRIGUES, M.L.K.; MINELLA, J.P.G.; MATSUMOTO, S.T.; VARGAS, V.M.F. 2012. Run off of genotoxic compounds in river basin sediment under the influence of contaminated soils. Ecotoxicol Environ Saf..75:63-72. https://doi.org/10.1016/j. ecoenv.2011.08.007

COSTA, T.C.; BRITO, K.C.T.; ROCHA, J.A.V.; LEAL, K. A. RODRIGUES, M.L.K.; MINELLA, J.P.G.; MATSUMOTO, S.T.; VARGAS, V.M.F. 2017. Corrigendum to: Runoff of genotoxic compounds in river basin sediment under the influence of contaminated soils [Ecotoxicol. Environ. Saf. 75 (2012) 6372]. Ecotox. Environ. 143: 351-352. https://doi.org/10.1016/j. ecoenv.2017.05.026

FEPAM, 2010. Vargas, V.M.F. (coord.). Estratégias ecotoxicológicas para caracterizar áreas contaminadas como medida de risco á saúde populacional. [Ecotoxicological strategies to characterize contaminated areas to as a measure of population health risk]. Porto Alegre. Eco-Risco Saúde Project Report.

IARC (Internacional Agency for Reserch on Câncer). 2010. Monographs on the evaluation of carcinogenic risks to humans, 2010. Some non-heterocyclic aromatic hidrocarbons and some related exposure. IARC, Lyon, 92:33-110.

POHREN, R.S.; ROCHA, J.A.V.; LEAL, K.A.; VARGAS, V.M.F. 2012. Soil mutagenicity as a strategy to evaluate environmental and health risks in a contaminated area. Environ. Int. 44:40-52. https://doi.org/10.1016/j.envint.2012.01.008

SINGARE, P.U. 2015. Studies on polycyclic aromatic hydrocarbons in surface sediments of Mithi River near Mumbai, India: Assessment of sources, toxicity risk and biological impact. Mar Pollut Bull. . 101: 232-242. https://doi.org/10.1016/j. marpolbul.2015.09.057

USEPA (United States Environmental Protection Agency). 2007. Method 3550C. Disponível em: /http://www.epa.gov. Acesso em: 7 Jan. 2015. 